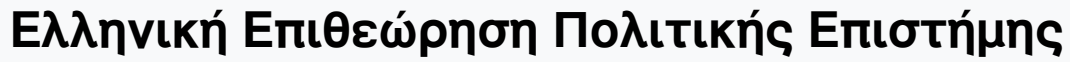

Tó 40 (2013)

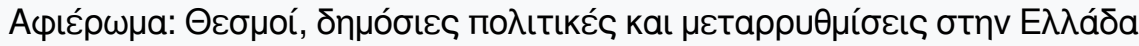

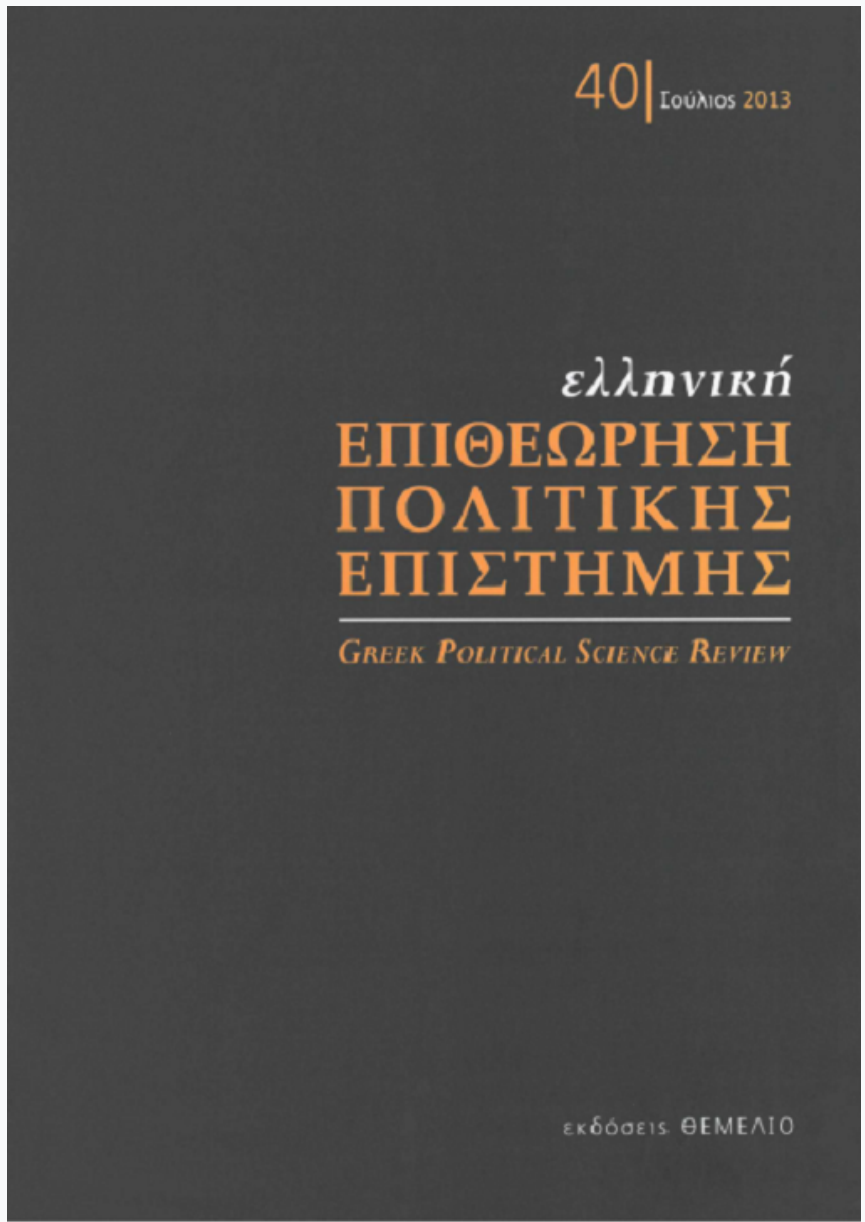

"Who is going to reform the reformers?" The coordination of the Greek National Reform Programmes

George Andreou

doi: $10.12681 /$ hpsa.14561

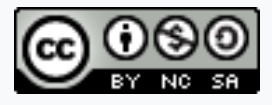

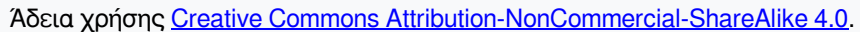

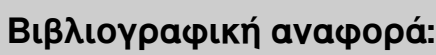

Andreou, G. (2017). "Who is going to reform the reformers?" The coordination of the Greek National Reform

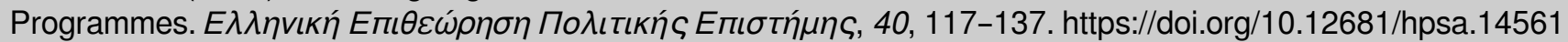




\section{"WHO IS GOING TO REFORM THE REFORMERS?" THE COORDINATION \\ OF THE GREEK NATIONAL REFORM PROGRAMMES}

\section{George Andreou*}

The article studies the impact of the revised Lisbon Strategy -and the National Reform Programmes (NRPs) in particular- on the EU policy coordination of Greece. It is argued that the structures and processes established for the formulation and monitoring of the NRPs reflect some deep-rooted characteristics of the Greek system of governance, namely centralism, politicization, informality and reliance on actors. It is also found that the demise of this policy network was caused not by domestic factors or developments, but by the insistence of Greece's EU partners to fuse the implementation of the Greek NRP with the execution of the 2010 economic adjustment programme. The introduction of this process of coercive-direct Europeanization in Greece (as well as in Ireland and Portugal) signals, inter alia, the emergence of a two-speed "Europe 2020". On the other hand, the new reform coordination process in Greece relies on preexisting structures and processes that closely follow traditional patterns.

\section{INTRODUCTION}

The national co-ordination of EU issues has always been a challenge for member states, forcing them to deal with multiple policy areas cutting across different organizational boundaries at the national level. The Lisbon Strategy has increased significantly that challenge, as its ambition to address complex problems (associated with the improvement of the European competitiveness) has expanded the number of policy areas member states need to co-ordinate. On top of that, the nature of the Open Method of Co-ordination (OMC)

* George Andreou is a Lecturer at the Deparrment of Political Sciences of the Aristotle University of Thessaloniki, Greece. 
used in the Lisbon Strategy defies the dominance of legislation as policy tool. ${ }^{1}$ In institutional terms, "Lisbon" does not constitute a policy space, but a governance architecture: a strategic and long-term institutional arrangement addressing strategic and long-term problems in a holistic manner, setting substantive output-oriented goals, and being implemented through combinations of old and new organizational structures. ${ }^{2}$

It can be argued that public policy in Greece -defined by centralization, politicization, hierarchical decision-making, poor vertical and horizontal coordination, low levels of policy efficiency and lack of transparency and accountability- exhibits a high degree of misfit with the logic of "Lisbon". The launching of National Reform Programmes (NRPs) in 2005 under the reformed Lisbon Strategy represented an additional challenge, as it necessitated the establishment of a novel coordination mechanism at the national level, and, furthermore, added new requirements for policy effectiveness and policy coherence. This paper employs an approach inspired by historical institutionalism in order to study the actors involved and the processes employed in the drafting and monitoring of the Greek NRPs; it thus aims to assess the governance and Europeanization effects of the Lisbon Strategy on the patterns of national EU policy co-ordination. In other words, following Borrás and Peters, our goal is to investigate empirically, first, whether there is an impact on the organizational structures of national EU policy co-ordination in Greece since 2005, and second, if there is change, what characterizes it. ${ }^{3}$

The term Europeanization describes processes of constitution, diffusion and institutionalisation of formal and informal rules, procedures, policy paradigms, styles, "ways of doing things" and shared beliefs and norms. These are first defined and consolidated in the context of EU decision-making and then incorporated in the logic of domestic discourse, identities, political structures and public policies. ${ }^{4}$ Drawing on the policy transfer literature, a useful distinction may be drawn between Europeanization that is voluntary (i.e., em-

1. See S. Borrás - B. G. Peters, "The Lisbon Strategy's empowerment of core executives: centralizing and politicizing EU national co-ordination", Journal of European Public Policy, vol. 18, no. 4, 2011, pp. 525-545.

2. See S. Borrás - C. Radaelli, "The politics of governance architectures: creation, change and effects of the EU Lisbon Strategy", Journal of European Public Policy, vol. 18, no. 4, 2011, pp. 463-484.

3. Ibid.

4. C. Radaelli, "The Europeanization of public policy", In K. Featherstone - C. Radaelli (eds.), The politics of Europeanization, Oxford University Press, Oxford 2003, p. 30. 
braced by key domestic actors) and coercive (opposed by key domestic actors). Again, there may be a distinction here between direct and indirect impacts. Thus, voluntary-direct Europeanization would be the ready adoption of EU decisions in a given area; while voluntary-indirect would refer to adaptation of EU preferences and/or practices and/or policies in another area. Similarly, coercive-direct Europeanization refers to the compulsory acceptance of European preferences and/or practices and/or policies in a given area, while coercive-indirect refers to spillover consequences of coercive-direct Europeanization in one area to another. ${ }^{5}$

When trying to trace the Europeanization effects of an OMC process, our knowledge of Europeanization suggests that its impact will be differentiated across countries and will depend on factors such as the domestic opportunity structure and socialization effects, ${ }^{6}$ the capacity of state administrations to plan and implement the associated reforms, and, more generally, the institutional capacity of the state to respond to external pressures. ${ }^{7}$ Most of the literature devoted to the study of co-ordination of EU policies at the national level stresses the primacy of the administrative traditions of member states. These path dependence findings are also dominant in the Europeanization approach on changes in national executives. The strong empirical presence of national path dependence indicates that Europeanization does imply neither a homogenization of public administrative structures, nor a process towards a "single European administration". ${ }^{8}$ Europeanization is thus treated not as an endstate, but as a process leading to differentiated outcomes. ${ }^{\text {? }}$

To explore domestic institutional changes in Greece brought about by the

5. I. Bache - A. Marshall, "Europeanization and Domestic Change: A Governance Approach to Institutional Adaptation in Britain", Queen's Papers on Europeanization, No. $5 /$ 2004,: Queen's University, Belfast 2004, p. 6, http://www.qub.ac.uk/schools/SchoolofPolitics International StudiesandPhilosophy/FileStore/EuropeanisationFiles/Filetoupload,38447,en.pdf.

6. Socialisation may turn "local" domestic policy-makers into "cosmopolitans" who feel some sense of belonging to a common European elite. This socialisation effect would enhance the impact of peer pressure on domestic policy choices. C. Radaelli, "The Europeanization of public policy", op.cit., p. 54.

7. See V. Schmidt, The Futures of European Capitalism, Oxford University Press, Oxford 2002.

8. S. Borrás - B. G. Peters, "The Lisbon Strategy's empowerment of core executives: centralizing and politicizing EU national co-ordination", op.cit., p. 528.

9. C. Radaelli, "Europeanization: Solution Or Problem?", European Integration Online Papers (EioP), vol. 8, no. 16, 2004, pp. 4-5, eiop.or.at/eiop/pdf/2004-016.pdf. 
NRPs, a governance approach, drawing on the insights and tools of two related notions -the core executive and the Centre of Government-, is adopted. Most definitions of governance contain the idea that there is wide participation of public, private and voluntary actors in the policy process. In one sense, the governance approach reveals nothing particularly new: central government has always depended on other actors in the policy process (particularly for policy implementation). It is the degree of interdependence that has changed due to the scale of fragmentation and subsequent proliferation of actors involved in policy-making, whether driven by internal reforms (such as privatization and devolution) or external pressures (such as European integration and globalization). ${ }^{10}$

The notion of the core executive was developed in research on central government in the UK and includes all those organizations and structures that primarily serve either to combine and integrate central government policies, or act as final arbiters within the executive on conflicts between different elements of the government machine. ${ }^{11}$ These are usually the Prime Minister's Office (PMO) and the set of organizations directly depending on the Prime Minister. A similar concept is the one of the Centre of Government; the latter is defined as a central leadership hub facilitating co-ordination, collaboration and co-operation across the public administration, with the objective of securing a strong, coherent and collective strategic vision of where the country needs to go, and how it will get there. ${ }^{12}$ Behind both concepts lies the understanding that central government is not a monolith and that traditional domestic concepts of cabinet government and prime ministerial power do not provide the tools for us to investigate the interdependence that is at the heart of government. This emphasis on disaggregating government and on studying the interdependence between formal institutions and informal processes provides greater sensitivity to understanding the influence of central government in mediating the pressures of Europeanization. ${ }^{13}$

10. I. Bache, "Europeanization: A Governance Approach", paper presented at the European Union Studies Association (EUSA) 8th International Biennial Conference, Nashville, March 2729, 2003, p. 9.

11. B. Laffan - J. O'Mahony, "Managing Europe from an Irish perspective: critical junctures and the increasing formalization of the core executive In Ireland", Public Administration, vol. 85 , no. 1, 2007, p. 169.

12. OECD, Greece: Review of the Central Administration, OECD Public Governance Reviews, OECD Publishing, 2011, p. 43.

13. I. Bache, "Europeanization: A Governance Approach", op.cit., p. 10-11. 
In their attempt to capture the "Lisbon effect" on domestic EU policy coordination, Borrás and Peters have formulated three different (but interrelated) hypotheses. Specifically, they argue that when dealing with Lisbon Strategy matters, national executives' coordination institutions exhibit trends towards a) centralization, b) politicization and c) path-dependent changes reflecting a continuation of pre-existing institutional patterns. ${ }^{14}$ This paper seeks to address these issues in the Greek context. The first section outlines the main instruments and procedures of Lisbon and "Europe 2020". A short discussion of politico-administrative relations in Greece, with emphasis on the policy coordination dimension, follows. The next section focuses on the governance of the three Greek NPRs that have been adopted so far (2005-2008, 2008-2010 and 2011-2014). In this instance, a very salient question meriting attention is whether the -substantial- policy changes triggered by Greece's debt crisis signify a critical juncture that encourages a break with the past. The last section concludes.

\section{AN OVERVIEW OF THE REVISED LISBON STRATEGY}

\section{a. From Lisbon I to Lisbon II}

The original Lisbon Strategy was launched in 2000 as a response to the challenges of globalization and ageing. The European Council defined the objective of the strategy for the EU "to become the most dynamic and competitive knowledge-based economy in the world by 2010 capable of sustainable economic growth with more and better jobs and greater social cohesion and respect for the environment". Five years later, in Spring 2005, judging the results as "mixed", heads of state and government chose to refocus priorities on growth and employment and decided to streamline the Lisbon process. The main features of the new process were a longer programming period, a single set of Integrated Guidelines, and the preparation by member states of National Reform Programmes (NRPs). The essential political choice behind these decisions was twofold. First, the failure of the first Lisbon strategy (Lisbon I) was attributed neither to its goals nor to its principles, but rather to excessive complexity and inadequate process. Second, the lack of political

14. S. Borrás - B. G. Peters, "The Lisbon Strategy's empowerment of core executives: centralizing and politicizing EU national co-ordination", op.cit., p. 530-531. 
commitment on the part of member states was considered a major weakness. As a result, the revised Lisbon strategy (Lisbon II) put emphasis on national ownership and adopted a more diversified, bottom-up approach. ${ }^{15}$

Lisbon II was both similar to and different from Lisbon I. It was similar because the major aims remained unchanged and because the very rationale of a "soft" coordination of national reform policies through the Open Method of Coordination (OMC) was not questioned. At the same time, it was different because some of the initial objectives were downplayed and because the underlying governance model, where the European Commission played the role of a schoolmaster, was abandoned in favour of one in which it played the role of a coach (the idea was to stop lecturing the member states and to embark on a partnership with them instead). ${ }^{16}$ The whole procedure was reorganized into three major steps; namely, the definition of a set of European Integrated Guidelines, their implementation through three-year National Reform Programmes (NRPs) and the monitoring of progress on a country by country basis and collectively. The consolidation of Member State responses into a single Programme was designed to introduce greater coherence into the policy-making process and to make sure that the different agencies and levels of governance would act in a more cohesive way in pursuing reform, making for a less fragmented political and administrative "ownership" of the different policy areas. ${ }^{17}$

The Lisbon Strategy's overall impact on the economy and on national reform processes has been mixed. Whereas Lisbon managed to create a European consensus on reform contents, the delivery gap between commitments and actions was not closed. As a matter of fact, Lisbon has failed to deliver on several of its ambitious benchmarks and targets. Furthermore, well-performing Member States pressed ahead with more ambitious reforms, whilst others gradually built up a (sizeable) delivery gap. It is also worth stressing that the approach to NRPs differed considerably across Member States, with ambitious and coherent reform agendas for some countries contrasting with vague

15. See European Commission, "Lisbon Strategy Evaluation Document", SEC (2010) 114 final, February 2010, http://ec.europa.eu/europe2020/pdf/lisbon_strategy_evaluation_en.pdf.

16. J. Pisani-Ferry - A. Sapir, "Last Exit to Lisbon", Bruegel Policy Contribution, March 2006, pp. 1, 5-6, http://www.bruegel.org/download/parent/29-last-exit-to-lisbon/file/385-lastexit-to-lisbon-english.

17. K. Armstrong - I. Begg - J. Zeitlin, "JCMS Symposium: EU Governance After Lisbon", Journal of Common Market Studies, vol. 46, no. 2, 2008, pp. 413-450. 
and more descriptive agendas in others that lacked the backing of governments and national (and regional) parliaments. ${ }^{18}$ However, Lisbon's successor, "Europe 2020", while putting more emphasis on innovation, green technologies and social cohesion, preserved the procedures defined in $2005 .{ }^{19}$

\section{b. Lisbon II and Europe 2020 in practice: the main actors and processes at the EU level}

The "streamlined" and "improved" governance architecture of Lisbon II was based on two three-year cycles, the first one from 2005-2008 and the second one from 2008-2010. The Integrated Guidelines adopted by the Council on the basis of the Commission's proposal served as the starting point for the first cycle. On the basis of the Integrated Guidelines, Member States elaborated NRPs, adjusted to their specific national situation, until October 2005. As a counterpart, the Commission drew up a Community Lisbon Program me covering all actions to be undertaken at Community level. In each of the two the two following years (2006 and 2007), Member States sent an annual report on the implementation of the Lisbon strategy to the Commission. Before generating a new report, the European Commission bilaterally visited Member States in order to assess progress and to submit country-specific policy recommendations to the Member States on how to improve delivery. This assessment built the basis for the Annual Progress Report, published by the Commission at the beginning of each year as part of the preparation of the Spring Council. Then, at its Spring summit, the European Council reviewed progress, pronounced on the Commission's recommendations, and decided on necessary modifications of the Integrated Guidelines. In 2008, Member States were asked to formulate a new NRP, thereby starting the next policy cycle.

On 26 March 2010, the European Council agreed to the European Commission's proposal to launch the 'Europe 2020' strategy. This strategy was finalized in the June 2010 European Council, which also introduced the concept of a "European Semester", bringing together macro-economic policy developments and structural reforms under Europe 2020. The "European Semester" is a time-window in the first half of each year, in which Member States reporting under the Stability and Growth Pact and reporting under the

18. European Commission, "Lisbon Strategy Evaluation Document", op.cit.

19. S. Borrás - C. Radaelli, "The politics of governance architectures: creation, change and effects of the EU Lisbon Strategy", op.cit., p. 465. 
Europe 2020 Strategy are aligned, and policy guidance and recommendations are given to Member States before national budgets are finalized. ${ }^{20}$ Thus, since the second half of 2010, the pre-existing policy cycle has been modified in order to take account of the requirements of the European Semester. Whilst the Commission fulfills the driving role by starting off the Semester with the Annual Growth Survey, the priority actions that it puts forward are debated in the various Council configurations, as well as in the European Parliament, before being adopted by the European Council. The recommendations -drawing not only on the examination of the NRPs, but also of the Stability and Convergence Programmes- directed to the Member States at the suggestion of the Commission similarly form the subject of discussion before being ratified by the European Council. ${ }^{21}$

At the European level, the system of governance developed around the NRPs relies on the close cooperation between the Council and the Commission. Political guidance and authority is provided by the Council, assisted by four advisory committees - the Economic Policy Committee (EPC), the Economic and Financial Committee (EFC), the Employment Committee (EMCO) and the Social Protection Committee (SPC). These committees are unique in the sense that they hold a position between the Council and the Commission. Although these are formally preparatory committees under the Council, the Commission handles their Secretariats and is also a full member of each one. The committees are to supply opinions on request of either the Council or the Commission. These committees do not fit the traditional pattern of the EU policy process in another respect: since the OMC is not a legislative process, normally there are no Comm ission or Council working groups involved, nor any comitology committees involved in the implementation phase. $^{22}$

During the period 2005-2009, each October, the finalized NRP report was

20. European Commission, "Europe 2020; A strategy for smart, sustainable and inclusive growth", Communication from the European Commission, COM(2010) 2020 final, March 2010, http://eur-lex.europa.eu/LexUriServ/LexUriServ.do?uri=COM:2010:2020:FIN:EN:PDF.

21. P. Heuse - H. Zimmer, "The Europe 2020 strategy", Economic Review, National Bank of Belgium, 2011, issue 2, Brussels 2011, pp. 30-31, http://www.nbb.be/doc/ ts/publications/ EconomicReview/2011/ecorevII2011_H2.pdf.

22. K. Jacobsson - E. Vifell, "Deliberative Transnationalism? Analysing the Role of Committee Interaction in Soft Co-ordination", in C. Meyer - I. Linsenmann - W. Wessels (eds.), Economic Government Of The EU; A Balance Sheet of New Modes of Policy Coordination, Palgrave, Basingstoke and New York 2007, pp. 168-169. 
forwarded to Brussels, where it was transmitted to the EPC. In the EPC, a twotier process of multilateral surveillance took place, whereby countries examined one another's NRP. This process was quite intensive and ultimately fed into the Commission's Annual Progress Report. The Commission's report contained proposals for country-specific recommendations, which served as the basis for a second, more targeted round of multilateral surveillance in January. The country-specific recommendations were then discussed in the EPC, the EFC and the EMCO, and were finally signed off by the ECOFIN in March.

Drawing on the typology developed by Bache and Marshal,.$^{23}$ the delivery mechanism of Lisbon II represents a policy regime of voluntary-indirect Europeanization: member states are being encouraged to adapt a significant number of their public policies to EU pressures and practices through policy transfer and learning. This has been reflected in the Lisbon Strategy's two specific requirements that might affect organizational features of national executives, namely, the preparations for the Spring Councils and national reform plans (upstream dimension of national co-ordination), and the multiannual programming and cyclical reporting requirements (downstream dimension of national co-ordination). ${ }^{24}$ This general approach was retained in the context of the "Europe 2020" strategy; only after the advent of the 2010 debt crisis would this model be seriously reconsidered. ${ }^{25}$

\section{POLITICO-ADMINISTRATIVE RELATIONS AND POLICY COORDINATION IN GREECE}

\section{a. Public policy in Greece: the main traits}

Using Schmidt's typology on the nature of European democracies, ${ }^{26}$ Greece is a simple polity par excellence, combining a unitary state structure, a majoritarian system of representation and statist policy-making processes. ${ }^{27}$ The

23. I. Bache - A. Marshall, "Europeanization and Domestic Change: A Governance Approach to Institutional Adaptation in Britain", op.cit.

24. S. Borrás - B. G. Peters, "The Lisbon Strategy's empowerment of core executives: centralizing and politicizing EU national co-ordination”, op.cit., p. 529.

25. See section 4.2 and the Conclusions of this article.

26. See V. Schmidt, Democracy in Europe, Oxford University Press, Oxford 2006.

27. K. Featherstone - D. Papadimitriou, The Limits of Europeanization; Reform Capacity 
overall context of policy-making is defined by the limited ability of state institutions to deliver reform. As Spanou put it, the Greek state has been "hypertrophied, omnipresent, but ultimately weak" ${ }^{28}$ The state's administrative complex is seen as suffering from internal problems of poor co-ordination; excessive legalism and hierarchical control; turf-fighting; the lack of high quality technical personnel; the inefficient use, and often the lack, of resources; clientelism and non-meritocratic norms; party infiltration; and the lack of permanency for senior positions. These features appear endemic to the administration, sustained across different governments. Hence, a) the Greek state has limited potential to introduce major structural reform (to liberalize the state's economic regulation, ownership and social support ${ }^{29}$ and b) while the record of institutional reform has been relatively more successful, there appears a serious implementation deficit. ${ }^{30}$

Reform initiatives are also hampered by the relationship between state institutions and wider society. First, interest mediation is constrained by a plethora of 'unofficial veto points', a distortion in favour of the interests of the public sector and the few large private corporations, an absence of trust between the key actors and the weakness of a "social dialogue". Second, there is an absence of a relevant policy community or think-tanks to affect actor interests or to offer legitimation to government reform strategies. Unavoidably, then, in sensitive policy sectors (such as social, employment and education policies), public understanding of the implications of reform (and of a failure to reform) is low and vulnerable to political manipulation. Third, the electoral cycle constrains the priority, content and timetable for reform: the scope

and Conflict in Greece, Palgrave Macmillan, Basingstoke 2008, pp. 52-53; G. Andreou, "The domestic effects of EU cohesion policy in Greece: Islands of Europeanization in a sea of traditional practices", Southeast European and Black Sea Studies, vol. 10, no. 1, March 2010, p. 14.

28. C. Spanou, "On The Regulatory Capacity of The Hellenic State: A Tentative Approach Based on a Case Study", International Review of Administrative Sciences, vol. 62, no. 2, June 1996, pp. 219-237.

29. K. Featherstone, "'Soft' Co-Ordination Meets 'Hard' Politics: the European Union and Pension Reform in Greece", Journal of European Public Policy, vol. 12, no. 4, 2005, pp. 733-750; K. Featherstone - D. Papadimitriou, The Limits of Europeanization; Reform Capacity and Conflict in Greece, op.cit., pp. 41-45.

30. C. Spanou - D. Sotiropoulos, "The Odyssey of Administrative Reforms in Greece, 1981-2008: A Tale of Two Reform Paths", Public Administration, vol. 89, no. 3, 2011, pp.723-737. 
for bolder reform initiatives lies early in the cycle, with softer and more limited reform attempts likely later in the cycle. ${ }^{31}$

\section{b. EU Policy coordination in Greece}

In terms of policy coordination, the most manifest systemic trait of the Greek state is the lack of an effective core executive or Centre of Government. ${ }^{32}$ Right until the outbreak of the domestic debt crisis in 2010, the Prime Minister's Office (PMO) was not a functional equivalent of a strategic planning unit, as its role was to monitor the work of ministers and follow up the evolution of government policies. ${ }^{33}$ Hence, the PMO primarily assumed an ex post coordination function. Key policy functions were distributed across different ministries and there was very little inter-ministerial and intra-ministerial coordination. The administration generally used to operate in silos. Fragmentation and overlaps among structures and tasks discouraged co-operation; unavoidably, then, collective commitment to a reform agenda was absent. Co-ordination, where it happened, was usually ad hoc, based on personal knowledge. ${ }^{34}$

In sum, most coordination mechanisms in the Greek government are informal. The PMO discusses policy proposals with ministers in ad hoc meetings; individual Ministers inform one another of policy initiatives over the phone or in brief personal meetings; and advisers to the Prime Minister confer with Ministers on policy issues when the Prime Minister selectively invites Ministers to the PMO headquarters for consultation. Line Ministries' higher civil servants are not normally involved in either the formulation or the coordination of policy proposals. Most policy preparation is done by political appointees, typically pro-government academics, experts and governing party cadres who form the Minister's entourage. These appointees staff a unit at the

31. K. Featherstone, "'Soft' Co-Ordination Meets 'Hard' Politics: the European Union and Pension Reform in Greece", op.cit., pp. 738-739; K. Featherstone - D. Papadimitriou, The Limits of Europeanization; Reform Capacity and Conflict in Greece, op.cit., pp. 200-201; K. Featherstone, "The Greek Sovereign Debt Crisis and EMU: A Failing State in a Skewed Regime", Journal of Common Market Studies, vol. 49, no. 2, 2011, pp. 195-198.

32. For a detailed analysis, see K. Featherstone - D. Papadimitriou, "The Emperor has no Clothes! Power and Resources within the Greek Core Executive", Governance, vol. 26, no. 3, 2013, pp.523-545.

33. Bertelsmann Stiftung, Sustainable Governance Indicators (SGI) 2011; Greece report, 2011, p. 31, http://www.sgi-network.org/pdf/SGI11_Greece.pdf.

34. OECD, Greece: Review of the Central Administration, op.cit., p. 17. 
peak of each Ministry's hierarchy, called the "political bureau of the minister" (the functional equivalent of the French "cabinet ministerial"). ${ }^{35}$ More generally, personal networks and commitment are important explanatory factors for successful operation and performance. The prevalence of agency over structure tends thus to be a permanent feature of the Greek politico-administrative system. ${ }^{36}$

When looking at the patterns of national co-ordination of EU policy, there are two fundamental dimensions. The first dimension is the level of centralization or decentralization within the executive. This has to do with the relative role attributed to core executives (or Centres of Government) vis-à-vis the role of sectoral ministries with traditionally high profile in EU matters (mostly the Foreign Ministry, Ministry of Economics and Finance Ministry). The second dimension concerns the role of bureaucrats vis-à-vis that of politicians. This dimension deals with the exercise of leadership in the national process of co-ordination of EU matters, meaning whether this leadership is mostly exercised by elected politicians or by civil servants. ${ }^{37}$

Since Greece's accession to the EU, the leading role in EU policy coordination was been oscillating between the Ministry of Foreign Affairs and the Ministry of Economy and Finance. The former was (and still is) formally in charge of political and/ or high policy issues, while the latter was responsible for economic policy issues. In practice, however, the 'coordination ambition' of both Ministries was low and, in many cases, line Ministries tended to exhibit a high degree of autonomy. ${ }^{38}$ On top of that, no there were no functional structures for inter-ministerial EU policy coordination on a permanent basis. ${ }^{39}$ After the government turnover of 2009, the Ministry of Economy and Finance was dismantled, and it was the Ministry of Finance that inherited the

35. Bertelsmann Stiftung, Sustainable Governance Indicators (SGI) 2011; Greece report, op.cit, p. 35.

36. C. Spanou, "Managing Europe from home: the Europeanization of the Greek Core Executive", Occasional Paper 4.1, Organising for EU Enlargement Project, 2004. http:// www.oeue.net/papers/greece-theeuropeanisationofthe.pdf.

37. S. Borrás - B. G. Peters, "The Lisbon Strategy's empowerment of core executives: centralizing and politicizing EU national co-ordination", op.cit., p. 529-530.

38. See C. Spanou, "Managing Europe from Home: the Europeanization of the Greek Core Executive", op.cit.

39. See A. Passas - E. Petraki, "Greek Administration in the EU Policy Process", in A. Passas - T. Tsekos (eds.), National Administration and European Integration; the Greek Experience, Papazisis Publications, Athens (in Greek). 
coordinating competences for economic policy, with the exception of the coordination of EU cohesion policy (which is now a competence of the Ministry of Development and Competitiveness). Thus, the overall picture is one of decentralization (or fragmentation) coupled with a high degree of informality and fluidity. At the same time, the prevalence of politicians over bureaucrats is unquestionable (one partial exception being cohesion policy, which is entrusted to a task-specific management network operating "outside" the mainstream administration). ${ }^{40}$

Turning into intra-ministerial policy coordination, whilst most ministries do not possess a permanent strategic planning unit, some have acquired a functional equivalent. The most prominent of these is the Council of Economic Advisors (SOE), which lies in the Ministry of Finance (until 2009 in the Ministry of Economy and Finance). SOE falls directly under the jurisdiction of the Minister of Finance. ${ }^{41}$ It has been granted an advisory role in economic policy developments, including ECOFIN matters. More importantly, its president is an alternate member of both ECOFIN and Eurogroup, and its members represent Greece in all Council groups under ECOFIN, including the Economic and Financial Committee (EFC), the Economic Policy Committee (EPC) and their sub-committees. ${ }^{42}$ On top of that, SOE is responsible for updating the national Stability and Growth Programmes. In 2005 SOE was also granted the responsibility for coordinating the drafting and the annual updating of Greece's National Reform Programmes. After the Greek debt crisis erupted (2010), the Greek government used SOE members as advisers and negotiators (though not as official national representatives) in the encounters between Greece and the European Commission and in the negotiations with the IMF. As it will be illustrated in the next section, since the adoption of the "Economic Adjustment Programme for Greece", SOE is also assisting the Ministry of Finance in monitoring the Programme's implementation. ${ }^{43}$

40. G. Andreou, "The domestic effects of EU cohesion policy in Greece: Islands of Europeanization in a sea of traditional practices", Southeast European and Black Sea Studies, vol.10, no. 1, March 2010, pp. 13-27.

41. SOE is composed by its president and a five-member Scientific Council, selected by the Minister of Finance for a 3-year term, an eight-member Economic Research and Analysis Unit (whose members are selected by the SOE's president also for a 3-year term) and a Secretariat.

42. It should be noted that the Ministry of Labour, which is in charge of representing Greece in the Employment Council and the two Lisbon-relating committees (the Employment Committee and the Social Protection committee) does not possess such a unit.

43. Interview with a SOE official, 10/5/2012. 
Greek policy-makers initially viewed the OMC with mistrust and reservation. This attitude comes from the inability of a state-centered society to come to terms with decentralized and participation processes, the absence of a civil society that could claim participation and the mistrust of trade unions towards a -very-centralized state with no intentions of promoting a genuine social dialogue. Both the government and the main political forces had favored the old Community method -as it brought immediate results and was, at least partly, financed by EU funds. ${ }^{44}$ In the course of the last decade, Greek politicians and top civil servants have progressively come to terms with the OMC but, as various reports and evaluations testify, they have not made a very efficient use of it. ${ }^{45} \mathrm{~A}$ study of the response of the Greek administrative system to the OMC in the field of pensions is particularly illustrating from an institutionalist viewpoint: it is revealed that, firstly, the OMC has not been very "open" (mobilizing only a small network of national civil servants and experts) and, secondly, that very little mutual learning has taken place. ${ }^{46}$

\section{THE STORY OF STRATEGIC PROGRAMMING IN GREECE, 2005-2012}

\section{a. The 2005-2008 and 2008-2010 NRPs: An experiment in policy coordination}

The Greek "National Reform Programme for Growth and Jobs 2005-2008" was drawn up in accordance with the guidelines issued following the relaunching of the Lisbon Strategy. The NRP -and the Lisbon Strategy as a whole- was coordinated by the Minister of Economy and Finance, Mr. G. Alogoskoufis -the first Greek "Mr. Lisbon"-, with the member of SOE and Economic Advisor to the Prime Minister, Ms. H. Louri, as deputy coordinator assisted by both SOE and the Economic Office of the Prime Minister. The Greek NRP started taking shape in March 2005 and was completed in October 2005 after having been presented and discussed at the Standing Committees on Economic and European Affairs of the Greek Parliament. At the

44. T. Sakellaropoulos, "Greece: The Quest for National Welfare Expansion Through More Social Europe", in J. Kvist - J. Saari (eds.), The Europeanization of Social Protection, Polity Press, Bristol 2007, pp. 211-227.

45. See, for example, S. Tilford - P. Whyte, "The Lisbon Scoreboard X; the road to 2020", Centre for European Reform, 2010, http://docs.minszw.nl/pdf/34/2010/34_2010_3_14100.pdf.

46. M. Angelaki, "Applying the Open Method of Co-ordination back home: The case of Greek pension policy", Social Cohesion and Development, vol. 2, no. 2, 2007, pp. 129-138. 
same time, the Economic and Social Committee (OKE) -an advisory body established in 1994 in the mould of the Economic and Social Committee of the EU- established an "Observatory for the Monitoring of Lisbon Strategy and Sustainable Development Policies", whose aim was to monitor the evolution of the reform process at the national level and to produce reports on an annual or bi-annual basis. ${ }^{47}$

In practice, the responsibility for the set-up and the operation of the coordination network was taken over by SOE, which established contact points with the line Ministries involved, organized a drafting procedure for the NRP (whereby each Ministry had to submit its own contribution within a specific deadline), carried out a series of consultation meetings involving the Ministries, regional authorities, Social Partners and NGOs and, after the Programme's submission in the EU, represented Greece in the multilateral surveillance processes in the framework of the EPC and the EFC. ${ }^{48}$ The driving force behind all this was the Lisbon's deputy coordinator, who, being a close partner of both the Prime Minister and the Minister of Economy and Finance, was able to "persuade" the line Ministries to cooperate in an effective and timely manner. ${ }^{49}$ In any case, all participants recognized that the new model of cooperation was constructive, and this assessment was reflected in the Commission's first annual assessment of the Greek NRP. ${ }^{50}$

The coordination network established in 2005 remained active throughout the duration of the first NRP. A noteworthy development was the creation of a Standing Lisbon Committee consisting of the competent Ministries, the Social Partners, the regions and NGOs. The establishment of this committee could possibly be considered as "best practice" ${ }^{51}$ and its prestige -was well as

47. Interview with an OKE official, 7/5/2012; Hellenic Republic - Ministry of Economy and Finance, "National Reform Programme for Growth and Jobs 2005-2008", Athens, October 2005, http://www3.mnec.gr/LISBON-NRP_EN_01-12-2005.pdf.

48. An interesting finding is that the Ministry of Labour was never able to take advantage of its strong institutional position at the EU level (being in charge of representing Greece in both EMCO and EPC). As a result, the dominant role of the Ministry of Finance (and SOE) has been never questioned.

49. Interview with a former SOE official, 24/5/2012.

50. European Commission, "Communication from The Commission to the Spring European Council; Time To Move Up A Gear - Country Chapters", Brussels, Part II to COM (2006)30, Brussels, January 2006, pp. 68-72, http://www.bmwf.gv.at/fileadminuser_upload/ europa/lissabon/forschung_lissabon_fs2.pdf.

51. Hellenic Republic - Ministry of Economy and Finance, "National Reform Programme 
its members' commitment- was certainly enhanced by the Commission's initiative to introduce yearly meetings in Athens. ${ }^{52}$ Moreover, OKE's Lisbon Observatory expanded its activities by undertaking information communication initiatives with a wider range of stakeholders and citizens. ${ }^{53}$ Finally, the Federation of Greek Industries (SEV) started a systematic monitoring of the NRP's implementation. ${ }^{54}$ Thus, in its following assessments, the Commission continued to view the governance of the Greek NRPs in a favourable light, stating though that "more work is needed to step up cooperation between central, regional and local level". 55

Both the network around SOE and the Lisbon Committee retained an informal character, a fact that signified that their performance and survival depended largely on a) the level of commitment on behalf of SOE and b) the level of political backing that the latter was enjoying. These limitations became evident when Ms. Louri quit early in 2008 and the post of deputy coordinator remained vacant for several months. Inter-ministerial coordination became then more difficult (since no other SOE member enjoyed the political backing of the former deputy coordinator). Overall, though, the NRP coordination mechanism remained functional throughout 2008 (when the 2008$2010 \mathrm{NRP}$ was prepared) and 2009 (when the first annual implementation report for 2008-2010 was issued under a new government). ${ }^{56}$ On the other hand, OKE's Lisbon Observatory suspended its activities due to internal dissensions. ${ }^{57}$

for Growth and Jobs 2008-2010", Athens, October2008, pp. 5-6, http://ec.europa.eu/ archives/growthandjobs_2009/pdf/member-states-2008-2010reports/greece_nrp_2008_en.pdf.

52. Interview with a former SOE official, 15/6/2012. See also Hellenic Republic - Ministry of Economy and Finance, "National Reform Programme for Growth and Jobs 2005-2008; Implementation Report 2006", Athens, October 2006, p. 3, http://ec.europa.eu/archives /growthandjobs/pdf/nrp/EL_nrp_en.pdf.

53. Interview with an OKE official, 7/5/2012.

54. See the relevant webpage of SEV (in Greek), http://www.sev.org.gr /online/viewPos.aspx?cat $=6 \&$ mid $757 \&$ lang $=$ gr $\&$ Code $=$ Opinions.

55. European Commission, "Implementing The Renewed Lisbon Strategy For Growth And Jobs: A Year Of Delivery", Brussels, Part II to $\operatorname{COM(2006)} 816$ final, Brussels, 2006, p. 2, http://ec.europa.eu/archives/growthandjobs/pdf/1206_annual_report_greece_en.pdf.

56. Interview with a former SOE official, 24/5/2012.

57. Interview with an OKE official, 7/5/2012. It is noteworthy that in the -still availablewebpage of the Observatory, the latter is has been retitled "Observatory of Sustainable Development Policies" (i.e. any direct reference to 'Lisbon' has been deleted). 


\section{b. The 2011-2014 NRP: Greece in the "Memorandum era"}

In late 2009, a very serious sovereign debt crisis erupted in Greece. Unable to confront the problem, the Greek government was forced in April 2010 to ask bilateral financial assistance from Euro-area Member States and a Stand-By Arrangement from the International Monetary Fund (IMF). As a result, in May 2010 the European Commission, the European Central Bank (ECB) and the IMF agreed on a three-year financing package for a total amount of EUR 110 billion (loan commitments). This loan agreement was accompanied by a very strict conditionality identified in an ambitious "economic adjustment programme for Greece". The specific conditions for the release of loan installments on a quarterly basis were further detailed in a "Memorandum of Understanding" agreed with the Greek authorities. The adjustment programme foresaw comprehensive action on three fronts: (i) a fiscal consolidation strategy, supported by structural fiscal measures and better fiscal control; (ii) structural reforms in the labour and product markets to address competitiveness and growth; and (iii) efforts to safeguard banking system stability. This strategy was further specified in a very long list of reform measures -encompassing virtually all policy sectors- that were to be adopted and implemented by the Greek authorities according to a very strict timetable. Greece's progress at all fronts would be assessed on a quarterly basis by a joint mission of the ECB, the EC and the IMF -the infamous Troika. The transfer of each tranche of the loan was to be dependent on such scrutiny. ${ }^{58}$

The change brought about by the adoption of the Memorandum has been seismic for the politico-administrative system of Greece as a whole. Henceforth, the financial viability of the Greek state depends on the implementation of a very precise and demanding policy programme that has been largely imposed by Greece's creditors and that can be modified only with the consent of the EU and the IMF. On top of that, the strict conditionality of the Memorandum is incom patible with the logic of Europe 2020: the ex ante definition of specific policy priorities and detailed, sequenced and quantified policy measures leaves no room for policy discretion (not to mention experimentation). In this new policy environment, the government and the public administration were obliged to adjust their reform priorities and initiatives to the needs and the

58. See, among others, European Commission, "Commission Staff Working Paper; Assessment of the 2011 National Reform Programme and Stability Programme for Greece", SEC (2011)717 final, Brussels 2011. 
austerity logic of the adjustment programme. In practice, this means that the activities of almost every Ministry are being monitored by Troika officials on a quarterly basis, an obligation that represents a huge workload for those -few- civil servants or advisers that are in position to meet the Troika's requirements for policy information. In many cases, these persons were also involved in the NRP network, and were requested by SOE to provide their contributions in view of the 2011-2014 NRP. ${ }^{59}$

Under these conditions, most of the domestic policy actors participating in the NRP network became convinced that the NRP was becoming a 'luxury' or a 'meaningless exercise'. Thus, the participation of line Ministries in the drafting of the 2011-2014 NRP was minimal and the Lisbon Committee was not convened at all. ${ }^{60}$ As to the NPR itself, it was essentially repeating Greece's commitments contained in the adjustment programme and, in terms of content, it largely overlapped with the 2011-2014 Stability and Growth Programme. Accordingly, Greece's participation in the multilateral surveillance process was typical, as was the 2011 annual Council recommendations -in fact, a single recommendation, that is to "fully implement" the measures of the adjustment programme. ${ }^{61}$ Similar recommendations were made to Ireland and Portugal, the two other Eurozone members that had followed Greece into receiving financial assistance by the EU and the IMF and, in exchange, had adopted their own Memoranda; for the record, the adverb "fully" did not appear in the Irish and Portuguese texts. ${ }^{62}$ Taken together, the Council recommendations for Greece, Ireland and Portugal represent a turning point for "Europe 2020". In their effort to salvage the EMU policy regime, EU policymakers have acknowledged that the overall reform strategy of voluntary-indirect Europeanization is no longer appropriate for those member states that are

59. Interview with a former SOE official, 24/5/2012.

60. Ibid.

61. See Council of the EU, "Council Recommendation of 12 July 2011 on the National Reform Programme 2011 of Greece", Brussels 2011/C 213/04, July 2011, http://eur-lex. europa. eu/LexUriServ/LexUriServ.do?uri=OJ:C:2011:213:0012:0013:EN:PDF.

62. See Council of the EU, "Council Recommendation of 12 July 2011on the National Reform Programme 2011 of Ireland and delivering a Council opinion on the updated Stability Programme of Ireland, 2011-2015”, 2011/C 215/01, July 2011, http://eur-lex.europa.eu/ LexUriServ/LexUriServ.do?uri=OJ:C:2011:215:0001:0003:EN:PDF; Council of the EU, "Council Recommendation of 12 July 2011 on the National Reform Programme 2011 of Portugal, 2011/C 216/01, July 2011, http://eur-lex.europa.eu/LexUriServ/Lex UriServ.do?uri= OJ:C:2011:216:0001:0002:EN:PDF. 
unable to sustain the economic crisis by their own means. Instead, these second-rank members must focus on the strict conditionality of the Memoranda and the coercive-direct Europeanization it represents. In short, a two-speed "Europe 2020" has emerged.

Since 2010, Greece's reform agenda is being defined and scrutinized according to the provisions and revisions of the economic adjustment programmes. This process relies on a hierarchical and centralized approach to governance, with the Ministry of Finance being in charge of policy coordination. In institutional and procedural terms, reform priorities, actions and interdependencies are being specified, discussed and assessed on the basis of quarterly monitoring meetings of national representatives with representatives of the Troika. These meetings take place at three levels (technical, ministerial and central). At the technical level, members of the technical staff of the troika meet with the General Secretaries of each Ministry involved. Once technical issues are clarified, there are negotiations at ministerial level between the members of the Troika and the Ministers of each Ministry involved. The top-level negotiations take place between the members of the Troika, the Minister of Finance and the Minister or Ministers involved (if necessary). Again, SOE members are present in all meetings, though not as official negotiators; their task is to monitor developments and to inform the Minister of Finance. The significance of SOE as a source of expertise is highlighted by the fact that its president participates in all top-level meetings, assisting the Minister of Finance. ${ }^{63}$

Last but not least, the successive Greek governments that have assumed the task of implementing the economic adjustment programme have so far been reluctant to create any permanent policy coordination structure. This lapse is all the more remarkable, given that the modernization of public administration is one of the key goals of the programme and that the creation of a stable structure of inter-ministerial coordination holds a prominent place in the current administrative reform plans. ${ }^{64}$ Therefore, coordinating the implementation of the Memorandum still relies on pre-existing structures: the Ministry of Finance holds the general responsibility; important tasks are shared be-

63. Interview with a SOE official, 15/2/2013.

64. The legal framework for inter-ministerial coordination was adopted only in December 2012; at the time of writing, the operational implementation of the coordination is still to start. See European Commission - Task Force for Greece, 'Fourth Quarterly Report', April 2013, http://ec.europa.eu/commission_2010-2014/president/pdf/qr4_en.pdf. 
tween SOE and key Ministry services (primarily the General Directorate of Economic Policy); ${ }^{65}$ and the PMO is limited in monitoring developments. ${ }^{66}$

\section{CONCLUSIONS}

The findings of this paper confirm the hypothesis that the establishment of the NRPs would enhance politicization: the main coordination tasks were entrusted to political appointees who were directly accountable to their political superiors. However, it is harder to pronounce on the hypothesis that more centralization would occur. Officially, the role of "Mr. Lisbon" was handed over to the Minister of Economy and Finance (and later the Minister of Finance) and not to the PMO. Yet, in reality the overall responsibility was taken over by the deputy Lisbon coordinator -a top-level adviser that was both a SOE member (i.e., directly accountable to the Minister of Economy and Finance) and the Director of the Economic Office of the Prime Minister. Furthermore, all major co-ordination tasks were entrusted to SOE members and the PMO did not play any active role in the whole process. There appears thus to have been a tacit agreement between the PMO and the Ministry of the Economy and Finance that "Lisbon" would remain under the authority of the latter, while the former would exercise solely a supervisory function. Once again, the limitations of the Greek core executive (or Centre of Government) are becoming evident.

More importantly, evidence supports also the hypothesis that, in dealing with Lisbon Strategy matters, the Greek executive would introduce path-dependent changes reflecting a continuation of pre-existing institutional patterns. The policy pattern adopted for the coordination of the NRPs followed closely the pre-existing model of economic policy coordination. SOE, a preexisting, well-performing (by domestic standards) and "Europeanized" agency, was entrusted with the mission to carry out both the drafting of the NRP and Greece's representation in the monitoring procedures that were developed at

65. In late 2012, a" Special Service for the Monitoring of the Memorandum" was set up in the Ministry of Finance after much delay (its creation was proclaimed in the Memorandum itself).

66. Interview with a SOE official, 15/2/2013. On the other hand, it is highly plausible to assume that, since 2010, there have been many fluctuations in the unofficial balance of power between three different Prime Ministers and Ministers of Finance. 
the EU level. The initial success of this arrangement must be attributed: a) to the skills, personality, commitment and political clout of SOE's members -and of the deputy Lisbon coordinator in particular; and b) to the informal character of the whole scheme: as the creation of the NRP network was accompanied by no visible change in the inter-ministerial balance of power, it was acceptable to all major players. ${ }^{67}$

The very informality of the Greek NRP network marked also the limits of its success, as lack of institutionalization meant that it would be very vulnerable to change. To be fair, the change brought about by the adoption of the Memorandum made the survival of the network all but impossible. In the "Memorandum era", the coordination ambition of the Greek executive is -understandably- exhausted in successfully addressing the demands of the Troika on a quarterly basis, relying on path-dependent institutional patterns. What is perhaps less understandable is the readiness of Greece's EU partners (above all the Commission) to abandon completely the "soft coordination" logic of the Greek, Irish and Portuguese NRPs by subsuming their monitoring and implementation into the conditionality of the respective adjustment program mes. Firstly, this choice is conceptually flawed, since not all components of a NRP feed into the relevant adjustment program me. ${ }^{68}$ Secondly, resorting to hierarchy and centralization may be an appropriate method for pursuing fiscal consolidation, but is certainly far less effective for the purpose of structural reform. Lastly, the creation of a two-speed "Europe 2020" deals a severe blow to the coherence and credibility of the Lisbon governance architecture as a whole. This setback may produce serious disincentives for coordinated reform in the EU (unless of course a functional alternative of "Europe 2020" is developed).

67. Interview with a former SOE official, 24/5/2012.

68. Interview with a SOE official, 15/2/2013. 